\section{Conference}

\section{Circuit}

\title{
Toward a Bibliothèque Nationale des Arts
}

\author{
By Cheryl Spiese McKee
}

\section{The new library will result in improved access and services}

$\rightarrow$ ublic discussion on the new Bibliothèque de France has eclipsed another significant development. In early 1990 it was announced that the Bibliothèque Nationale's (BN) former facility in the Rue Richelieu would house a "Bibliothèque Nationale des Arts." As conceived by the government, this new national library of the arts will bring together several collections which are now physically dispersed and administratively unconnected: the Département des Estampes et de la Photographie (which will remain in its quarters in the present $\mathrm{BN}$ ); the Bibliothèque d'Art et d'Archéologie, the Bibliothèque Centrale du Louvre et des Musées Nationaux; the Bibliothèque de l'Ecole Nationale Supérieure des Beaux-Arts.

The first open, professional discussion of the project took place at a one-day conference in Paris on December 12, 1991, and was organized by the Paris group of the special libraries section of the "Association des Bibliothecaires Francais." Administrators from the affected libraries outlined the impact of the project on their institutions. An excellent analysis of the entire project was then followed by additional speakers representing various categories of "users" who presented their views of the impact of the new facility on their own work.

\section{Planning and timetable}

Recurrent criticism focused on the lack of consultation associated with the government's decision. Librarians, having had no input, must now work out logistics and problems. Officials were unaware of the tremendous complexities involved in relocating and consolidating the various collections and services, especially with regard to the projected timetable. For example, the process of readying materials for transfer has revealed numerous preservation issues which, ideally, should be addressed before any move.

Consolidation of the separate administrations poses major problems vis à vis personnel and reporting structure. Also, the relation of this library to the research institute and to the new Bibliothèque de France still remains to be determined. A working group called the "Association pour la Bibliothèque Nationale des Arts" has been established to address these administrative and policy issues.

\section{Defining "arts" and identifying collections}

Several speakers indicated that the most difficult task initially was defining the scope of "arts" and then identifying specific collections to be merged into such a library. The final choice was generally characterized as "arbitrary." Furthermore, disciplines such as archeology and architecture go beyond the traditional confines of "art" in their dependence on technical material. There were also questions concerning the noninclusion of other "arts" collections.

One speaker criticized the creation of yet another centralized, Paris-based collection and felt that resources could be better used to identify all major French art historical collections and to create a union catalogue. She emphasized the need to shift from the idea of "collection" (i.e., ownership) to "identification et communication" (i.e., access).

\section{Collection diversity}

While all the libraries have a core of traditional published material, other resources such as 
engravings, drawings, blueprints, and architectural models will require diverse treatment and modes of access. Concern was expressed for the disposition of each institution's internal archives, which exist independently of the collections, but which should be included in any moves since archival documentation concerning the institutions of art is increasingly important in tracing the history of art.

\section{Access and services}

It was generally agreed that the completed project should result in improved access and services since it will unite several dispersed collections in a single facility that is, in most respects, superior to the current ones. Preservation efforts would certainly be improved. However, issues concerning levels of service and access need to be resolved. The libraries have historically served different clienteles; the new facility will now serve them all, yet must avoid the "encyclopédisme" of being all things to all people. There is special concern on the part of those libraries whose mission has been primarily pedagogical that the association of the arts library with a research institute will restrict the access formerly enjoyed by students.

\section{Automation}

Merging the catalogues to provide improved bibliographic access presents a major challenge.

\section{(Murphy cont. from page 246)}

expressions of the art work as it is captured in the video presentation? 2) What does the presenter lose in ticket sales if video cameras take up seats that could be sold? 3) What are the things the performer considers important to be presented in each video piece? 4) Is the video being created for study, a grant application, or public relations? and 5) Where should the video document be kept? All of the panelists responded to these questions by expanding on some of the issues that they had addressed in Part I of the program on Saturday night. However, new subjects discussed included issues such as: 1) What kinds of other forms of documentation of a performance such as performer notes or masters of studio recordings and the like are available from the performer to supplement the video document? 2) Does the documenter or the performer or someone else own the copyright on any given work after it is
Centuries of independent practices have resulted in neither standardized cataloging nor standardized terminology. The task of "harmonizing" the separate catalogues will be immense, achievable only through a major automation effort that includes retroconversion. Computerization, therefore, is essential and should be at the heart of the project. Government financial support has so far focused on physical facilities, although the Louvre library has just been awarded a large sum to begin automating the catalogue of the Musées Nationaux. But more funding will be needed to consolidate and upgrade all the catalogues that will comprise the new infrastructure. Anticipating future developments, one speaker also envisioned the establishment of a "distance research" service, utilizing imaging technology, fax, scanning, etc. to provide materials to researchers located elsewhere.

\section{Conclusions}

The entire project will involve massive financial commitments and considerable upheaval for the institutions involved. That it will proceed is a given and, despite criticisms concerning its inception, the library professionals at this conference seemed committed to a workable solution. Several speakers emphasized that the project does provide a much-needed and long-overdue chance to reevaluate the various libraries' collections, services, and policies.

produced? 3) Are libraries presenting performance art videotapes instead of bringing in the actual performer? 4) How can funding for better documentation of performance art be distributed to documenters? and 5) How can library networking help to distribute information about performance art to persons who are interested in it no matter where they are? The session concluded with a question-and-answer period.

These two sessions were interesting because they were connected to one another and gave the participant who had the opportunity to attend them both a good understanding of the issues from the artist, the documenter, and the library point of view. In listening to each of the speakers it became increasingly apparent that libraries can be active participants in preserving and documenting performance art and that the artists and the documenters recognized that libraries could be a much needed impartial widespread distributor of their work. 